\title{
Mapping of Work Hazards Environment and Illness Risk of Employment on Brass Craftsman Based on Geographic Information System (GIS)
}

\author{
Sannita Debora Ambarita, ${ }^{1, *}$ Yuliani Setyaningsih², Daru Lestantyo², and Yudhy Dharmawan ${ }^{2}$ \\ ${ }^{1}$ Undergraduate Student of Occupational Safety and Health, Faculty of Public Health, Diponegoro University, Semarang - Indonesia \\ ${ }^{2}$ Department of Occupational Safety and Health, Faculty of Public Health, Diponegoro University, Semarang - Indonesia
}

\begin{abstract}
The brass craftsmen are exposed to the dangers of the working environment of work, and the hazard of occupational illness risks can also be experienced by workers. The purpose of this study is to analyze and map the hazards of work environment and risk of occupational diseases using Geographic Information System (GIS). This research is qualitative research. The sample was taken purposively by 10 brass craftsman in Juwana sub-district. Data on occupational illness risk complaints were taken using an in-depth interview questionnaire. Workplace hazard identification was analyzed using HIRA Form and hazardous workplace mapping using GIS software free (PC Arc 10.3). The research results showed that the hazard of working environment on brass craftsmen more is the physics hazard derived from the machine used. In addition, there is also a chemical hazard during the working process both steam and metal dust. The risk of occupational illness most of which the respondents complained of was shortness of breath and cough. In addition, arm pain and low back pain is also experienced by the workers. This research showed that the hazards of work environment on brass craftsmen include physical hazards, chemical hazards, ergonomic hazards and psychological hazards. While the complaints of occupational illness risk in the form of respiratory problems, arm pain, low back pain and skin irritation.
\end{abstract}

Keywords: Mapping; GIS; Enviromental hazards; Risk of occupational illness

\section{Introduction}

Industrialization is now a center of economic development and an increased opportunity for human well-being. The population working in the formal sector is 32.14 million people $(30.6 \%)$ while those working in the informal sector are more than twice that of 67.86 million $(69.3 \%) .{ }^{[1]}$ The small informal sector in general, involving low-educated, unorganized workers in work processes and temporary, partly unregulated and unregistered employment arrangements, is outside the state's rules and controls, including those related to $\mathrm{OSH}$ and social protection. Danger is a condition or behavior that could potentially cause accidents, damage or other disturbances. ${ }^{[2]}$

Hazards of workplace environmental consist of chemical hazards, physical hazards, biological hazards, ergonomic hazards, and psychological hazards. Decreasing exposure to chemicals in the work environment will have a good impact on the quality of the work environment. One of the dangers of chemicals is carbon. The quality of a good work environment will increase the productivity of its workers, making the work environment comfortable and efficient for its workers. Danger in the workplace can cause the risk of occupational diseases. Based on data from the Center for Data and Information Ministry of Health of the Republic of Indonesia there were as much as 40,694 cases of occupational diseases in 2014. ${ }^{[3]}$

Geographic Information System (GIS) is a system created so that someone can do any work using data related to a place on earth. A Geographic Information System can assist planners, policy-making, can as a tool to map and visualize disease risk issues, identify forms of disease spread, monitor surveillance and activities prevention of disease, estimating accessibility to health care facilities and estimating outbreaks of disease. ${ }^{[4]}$ It should also be applied in the workplace in both the informal and the formal sectors. The informal sector consists of various types of businesses and includes among others brass craftsmen. The brass craftsmen are informal sector jobs that use machines and chemicals in their work processes. Based on preliminary study that has been done there are 29 villages in District Juwana Pati Regency. Juwana Sub-district is famous for its brass craftsmen. In the process of brass processing there are many hazards such as noise, pressure, vibration, temperature, chemicals, etc. originating from the

\footnotetext{
Corresponding author: mailto:nithadebo@gmail.com
} 
identifiable production process. Juwana sub-district as business centers of brass craftsmen certainly has the potential hazards that exist in the work environment. In addition to the danger, the risk of occupational illness can also occur as a result of the potential hazards that exist in the work environment. Efforts to control occupational hazards and the risks of occupational illness can be done by mapping. The purpose of this research is to analyze and to map work hazard of work environment and risk of illness by using geographic information system (GIS) as one of controlling worker of brass craftsman in Juwana Sub-district.

\section{Method}

The type of this research is qualitative research with the aim to know the picture of work environment hazard and occupational disease risk on brass craftsman based on geographic information system (GIS). The population used in this study was UMKM and brass craftsman workers Juwana district and the sample in this study using purposive sampling that is as much as 5 UMKM and 10 workers as the object of research. Triangulation Informant in this research is 1 stakeholder of Juwana Public Health Center who handles job health section of informal sector in Juwana Sub-district.

\section{Results and Discussions}

\subsection{Mapping Spread of UMKM Brass Craftsmen}

\section{Picture 1. Map Spread of UMKM Brass Craftsmen}

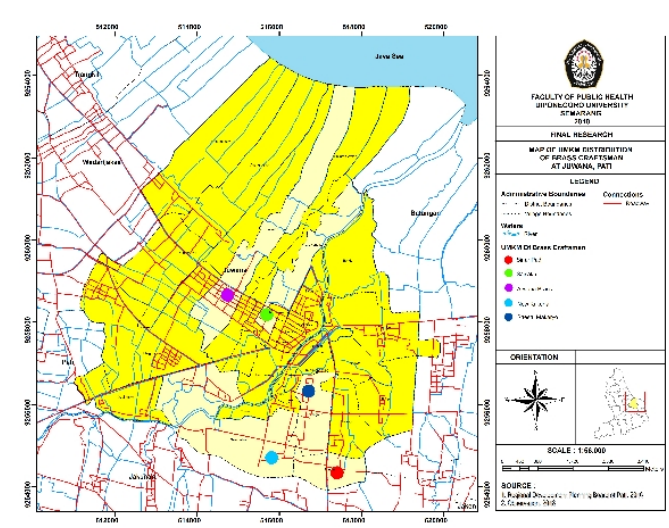

The mapping conducted in 5 UMKM is: UMKM Saestu Makaryo located in Karangrejo Village, UMKM Sinar Padi located in Bringin Village, UMKM Saisaku located in Growong Lor Village, UMKM Arwana Brass located in Bakaran Kulon Village, and UMKM New Kakeda in Senjomulyo Village.

\subsection{Mapping Working Process of Craftsmen Brass}

Pictures 2. Map Process of Brass Craftsmen

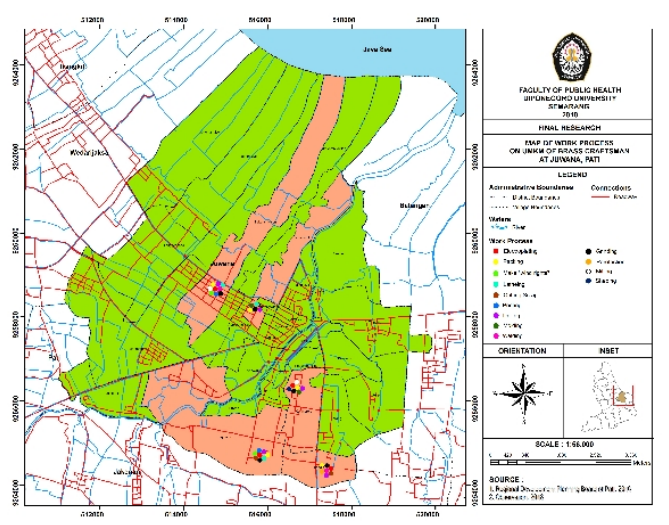

Based on the result of mapping, it indicated that work process at UMKM brass craftsman in District Juwana by using Geographic Information System (GIS) tend to similar. Based on the results of analysis and observation in the field, it was found that there were 13 types of work processes in 5 UMKM brass craftsmen in District Juwana. This slightly different work process is in accordance with the demand of each UMKM consumer.

\subsection{Mapping Environmental Hazards Analysis}

Pictures 3. Map Environmental Hazards of Brass Craftsmen

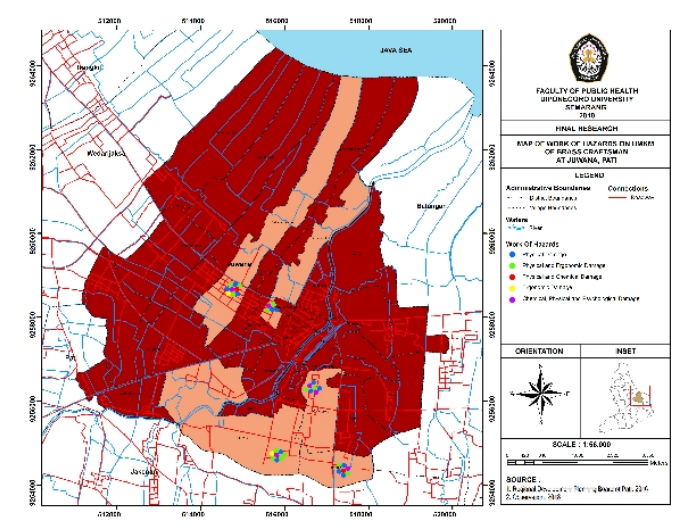

Based on the result of mapping, it indicated that the spread of work environment hazard to UMKM of brass craftsmen in Juwana Sub District by using Geographic Information System (GIS) tend to have the similar work environment hazard. This is evidenced by a similar workflow process in each UMKM. However, it was found out that UMKM Sinar Padi have a higher work environment hazard compared to 4 other UMKM. The reasons are the number of workers who reach almost 50 people; it has 2 places of production warehouse; it is using more machines for the production process; the number of targets each day reaches 400 pcs per day. According to Tarwaka, every production process, equipment, or machine in the workplace used in production always has certain potential hazards which, if 
it is neglected, may result in the illness risk of occupational injuries. ${ }^{[5]}$ Observation results using HIRA Form in 5 UMKM craftsman Kuningan Juwana-Pati District identified the existence of physical, chemical, ergonomic and psychological hazards in the workplace. The description can be seen in Picture 3.

Physical hazards arising from machines operating within the work area create noise causing the risk of hearing loss to workers, metal dust and iron filings that can cause eye irritation and respiratory system disturbances. In the grinding work process there are sparks coming from the machine, noise and vibration. Hazards in the welding process are the dangers of radiation (light), the dangers of smoke and gas, the dangers of sparks, the danger of fire, and the danger of electricity. ${ }^{[6]}$

Chemical hazards, derived from chemicals used in the electroplating process. The chemicals used are chrome and nickel. Chr (chromium) is a relatively unstable and easily oxidized white hard metal, polished to shiny. There is also a chemical hazard to the casting process. Casting is the process of forming objects by liquefying metal and pouring into mold holes. Pollution of chemical substances in the natural casting chamber gives a bad impact on the health of workers. Casting rooms are filled with the presence of chemical substances due to the process of smelting metal, will certainly have an impact on the emergence of various types of occupational diseases. $^{[7]}$ The psychological hazard is arising from a hot workplace. In 5 UMKM observed that their workplace is quite hot, there is a lack of air ventilation. Lack of air ventilation causes the workers' heat pressure. The layout of goods at each UMKM also still does not look neat. Heat stress is more likely to occur in the process of casting and electroplating work. Since casting uses fire for the combustion process, and electroplating contains chemical vapors thereby it makes the workplace atmosphere hotter. Husaini stated that a working climate or a hot temperature will affect the rate of chemicals reacting in the air especially in the worker where every work is always open. ${ }^{[8]}$

\subsection{Mapping Risk Occupational Illness}

Pictures 4. Map Risk Occupational Illness

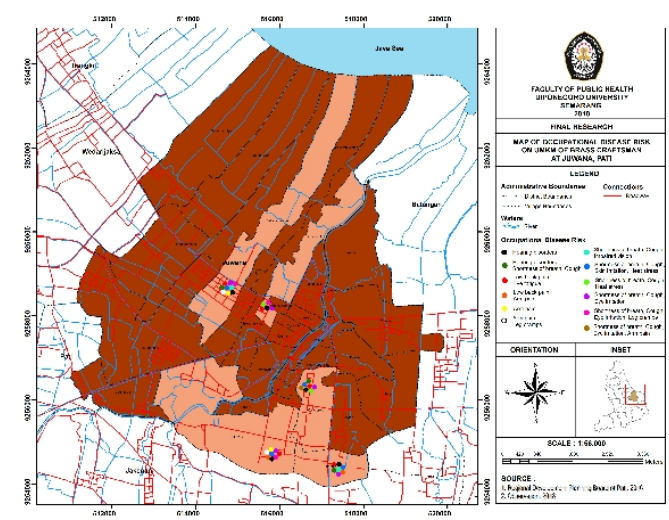

Based on the results of mapping, it indicated that the spread of risk of occupational illness on UMKM brass craftsmen in District Juwana by using Geographic Information System (GIS) tend to have the similar risk of occupational illness. The electroplating process (metal coating) is using chrome and nickel chemicals. Effects on health such as airway irritation can cause coughing, chest pain and shortness of breath, visual impairment such as conjunctive inflammation, lacrimation and dark red color around the cornea, as well as lung cancer and skin irritation such as itching or allergies. ${ }^{[7]}$ Based on Setyaningsih research, it stated that the disease risk complaints in metal coating workers are itching, coughing, shortness of breath, and musculoskeletal complaints. ${ }^{[9]}$ Zeins said that high chromium content can affect respiratory symptoms and bronchial asthma increase. ${ }^{[10]}$

Several informants complained of eye irritation due to metal dust and reduced vision. The flake of metal powder getting in the eye is small and sharp. When it gets to the eye it will redden the eye and it will cause irritation. Eye irritation can cause inflammation of the eye called conjunctivitis. Some brass craftsmen experience low back pain complaints, this happens due to sitting too long and doing monotonous work. The work process in brass craftsmen mostly are done in a sitting position. According to Tarwaka, although many people say that it is a light job to do the work in a sitting position, but in fact if it is done in a very long period even during the day then the work with a sitting attitude will be very tiring. ${ }^{[11]}$

Complaints of work stress were also found among the brass workers. This happens for several reasons that is because they does not meet the target, they cannot get good material for production so it results bad works, and they do not get work order. The results of this study are also in line with the research conducted by Syahfitri and Samosir in 2008 entitled Factors Causing the Work Stress of Librarians at the University of North Sumatra Library which shows that the factors causing stress on employees in terms of workload is a job demand that is sometimes too much, so employees have to work very much hard, and sometimes have to take time off to complete their work. ${ }^{[12]}$

As a result of the use of chemicals in the electroplating process some of the informants are irritated to the skin. These irritations cause itching and redness in the skin of the hands and feet of brass craftsmen. In the work process using machines that contain potential workplace hazards, most informants experience complaints of arm pain. This arm pain occurs by using the hand to move the machine during the production process. Repetitive upward-down movements cause pain in the arm.

\subsection{Risk Level Analysis of Craftsmen Brass}

From the data processing, classification of risk matrix level on brass craftsmen obtained 2 variables with very high risk level (Extreme risk) on electroplating work (metal coating) and welding. For high risk level (High risk) it was obtained 4 variables that are on the work of smoothing, grinding, casting and forwarding. For medium level risk (Medium risk) it was obtained 5 
variables that is on the work of smelting, cutting, lathe, and bending "right wind". For low risk level (Low risk) it was obtained 2 variables that are on the job of printing and packing.

\section{Conclusion}

Based on the research result that has been done, it can be concluded that:

1. In the 5 UMKM studied, all of them have a similar work environment hazard that is physical, chemical, psychological and ergonomic hazards.

2. The dangers of the work environment of brass craftsmen are more dominated by the physical hazards arising from the machines they use during work. Chemical hazards are also a danger to the working environment of brass craftsmen derived from the chemicals they use for the work process.

3. 5 UMKM who studied the risks of occupational illness mostly complained on the respiratory system such as shortness of breath, cough and colds.

4. In the 5 UMKM, the work environment hazard control has not been done well and maximally.

5. In 5 UMKM where the personal protective equipment was examined, the use of the equipment while working is still not applied properly.

\section{Suggestion}

Based on the results of research that has been done researchers give suggestions as follows:

5.1 For owners of UMKM brass craftsmen:

a. Because the complaint is exposed to sparks from the machine used should be given a cover on the machine.

b. Because of low back pain complaints and arm pain should be given stretching time for 15 minutes during work and provide personal protective equipment in the form of masks, boots, gloves, welded glasses and personal protective equipment in accordance with the type of work.

c. Create safe working procedures for example, posters or stickers at work.

d. Working together with puskesmas juwana to provide empowerment and assistance to the workers to give priority to safety and health while working.

5.2 For Puskesmas Juwana

Approach to the owners of UMKM brass craftsmen in District Juwana by providing health work materials. In order to prevent work accidents and work-related illness risk (PAK) on the informal sector of brass.

\subsection{For workers brass craftsmen}

a. Stretching while working to reduce complaints of low back pain and arm pain.

b. Consume 8 liters of water a day while working. Where, hot workplace can cause dehydration and heat stress.

c. More concerned about safety and health during work to prevent the occurrence of work accident.

\section{References}

1. Kementrian Lingkungan Hidup dan Kehutanan. Statistik Lingkungan Hidup Dan Kehutanan. 2016.

2. Heinz, Peter Berg. Risk Management : Procedures, Methods and Experiences. Germany: RT\&A\# 2 (17) (Vol.1) 2010, June.

3. Pusat Data dan Informasi Kementrian Kesehatan Republik I. Jakarta; 2015.

4. Sonti SH. Application of Geographic Information System (GIS) in Forest Management. J Geogr Nat Disast 5: 145. South Africa ; 2015.

5. Tarwaka, dkk. Ergonomics for Occupational Safety and Productivity Text Book, Edisi Pertama. Cetakan Pertama, UNIBA Press; 2004.

6. Bakti Husada. Occupational Disease Due to Exposure to Heavy Metal. Direktorat Bina Kesehatan Kerja dan Olahraga Kementrian Kesehatan Republik Indonesia; 2012.

7. Republik Indonesia. Presidential Decree No. 22 of 1993 concerning Diseases That Arise Due to Work Relations. President of the Republic of Indonesia:Jakarta; 1993

8. H. Husaini, N E S., H H. Marsetyawan Adi, Case Study: Correction of Measurement of Air Pollutants in the Metal Craftsman Unit and Its Impact on Health, Health Research Bulletin,Vol 44, No 2 .2016.

9. Setyaningsih, Yuliani, Adi Heru Husodo dan Indwiani Astuti. Work Environment Factors and Their Influence on Urinary Chorium Levels in Informal Elektroplating Workers. E3S Web of Conferences 31, 06007 (2018).

10. M. Zeins, C.I. Rivard, JL. Malo, D. Gautrin, Is Metal Fume Fever a Determinant of Welding Related Respiratory Symptomps and/or Increased Broncial Responsiveness 62. 688-694. (2005)

11. Tarwaka. Industrial Ergonomics.Harapan Press. Surakarta; 2010.

12. Syahfitri and Samosir. Factors that cause stress on the work of librarians at North Sumatra University companies Library and Information Studies Journal, Vol. 4 No.2. FKIP-Nort Sumatera :2008 